\title{
El Pueblo y la Nación: España en la literatura de cordel del siglo XVIII
}

\author{
Juan Gomis Coloma \\ Universidad Católica de Valencia "San Vicente Mártir" \\ juan.gomis@ucv.es
}

Fecha de recepción: 27/11/2011

Fecha de aceptación: 08/09/2012

\section{RESUMEN}

Este artículo indaga la posible contribución de la literatura de cordel del siglo XVIII en el proceso de construcción de una identidad nacional que tomó impulso en España en dicha centuria. Se analizan diversos pliegos sueltos que divulgaron contenidos patrióticos y se cuestiona el papel jugado por el poder político en la difusión de estas ideas. Finalmente, se da cuenta del proceso cultural por el cual, en el siglo posterior, esa literatura popular fue acrisolada por las elites intelectuales y convertida en uno de los pilares básicos de la construcción nacional en España. ${ }^{1}$

Palabras clave: Literatura de cordel, Literatura popular, Romances, Construcción nacional, Nación.

\section{People and Nation: Spain in Eighteenth-Century Cordel Literature}

\begin{abstract}
This article explores the contribution that eighteenth century cordel literature played in the construction of a national identity in Spain, analyzing several broadsides with patriotic content while discussing the role played by politics in this process. Finally, it approaches the cultural process by which, in the nineteenth century, popular literature was transformed by the intellectual elite into one of the main pillars in the process of Spanish national identity construction.
\end{abstract}

Key words: Cordel Literature, Popular Literature, Ballads, National Building, Nation.

1 Este artículo se ha realizado en el marco de los proyectos de investigación HAR2008-04113 y HAR201126129, financiados por el MICINN. 
A pesar de los numerosos trabajos que vienen abordando el complejo proceso histórico de formación de una identidad nacional en España, es escasa la atención que se ha prestado al papel que la literatura popular pudo jugar en dicho proceso. ${ }^{2} \mathrm{El}$ interés que, en mi opinión, presenta este descuidado ámbito de estudio es doble: por un lado está la cuestión de si estos textos masivamente consumidos contribuyeron en algún grado a la forja de ese sentimiento de pertenencia nacional, difundiendo determinados temas y personajes que despertaran cierta sensibilidad patriótica entre sus lectores, y si detrás de tales textos existió una voluntad política consciente por parte de las elites gobernantes. Por otro lado, el hecho de que la "cultura popular" fuera reinterpretada y asumida por el discurso nacionalista del XIX como la esencia del alma española, subraya asimismo la importancia del tema. Este artículo es una aproximación a ambos aspectos, mediante el análisis de los posibles contenidos "nacionales" presentes en la literatura de cordel del siglo XVIII en España, así como del proceso cultural por el que "lo popular", debidamente expurgado, se convirtió durante el XIX en sinónimo de "nacional".

Los estudios sobre la literatura popular en la España moderna han conocido un notable desarrollo en los últimos años. Gracias a los trabajos que continuaron la labor pionera de Antonio Rodríguez Moñino, Julio Caro Baroja o M ${ }^{\mathrm{a}}$ Cruz García de Enterría conocemos bien los temas y personajes que se fueron sucediendo durante los cinco siglos de vida de la literatura de cordel, así como los aspectos relativos a la materialidad de los impresos. ${ }^{3}$ Recientemente, como consecuencia de los progresos de la historia de la cultura escrita, a esta tradición investigadora se ha sumado una tercera vía de estudio cuyo objeto son los procesos de producción, difusión y lectura de los pliegos sueltos, con el fin de indagar en los diversos modos de apropiación de los textos por parte de sus lectores u oyentes. ${ }^{4}$ Estos trabajos y los que (esperemos) les seguirán en el futuro han venido confirmando lo que estudios anteriores solo podían intuir: el enorme volumen productivo del género de cordel

2 Sin pretender ser exhaustivo, véase Fernández Albadalejo, Pablo: Materia de España. Cultura política e identidad en la España Moderna, Madrid, Marcial Pons, 2007; Álvarez Junco, José: Mater Dolorosa: la idea de España en el siglo XIX, Madrid, Taurus, 2001; Portillo Valdés, José María: Revolución de nación. Orígenes de la cultura constitucional en España, 1780-1812, Madrid, Centro de Estudios Políticos y Constitucionales, 2000; Forcadell, Carlos y Romeo, María Cruz (eds.): Provincia y nación. Los territorios del liberalismo, Zaragoza, Institución Fernando el Católico, 2006; MARTí, Manuel y ArChILÉs, Ferran: «Una nació fracassada? La construcció de la identitat nacional espanyola en el llarg segle XIX», Recerques, 51 (2005), pp. 141-163. Entre los escasos estudios que han tratado la relación entre lo "popular" y lo "nacional", véanse los de Xavier Andreu Miralles: "De cómo los toros se convirtieron en fiesta nacional: los "intelectuales" y la "cultura popular" (1790-1850)», Ayer. Revista de Historia Contemporánea, 72 (2008), pp. 27-56; y «La mirada de Carmen: el mite oriental d'Espanya i la identitat nacional», Afers: fulls de recerca i pensament, 1948 (2004), pp. 347-367.

3 Caro Baroja, Julio: Ensayo sobre la literatura de cordel, Madrid, Revista de Occidente, 1969; RodríGUEZ Moñino, Antonio: Diccionario bibliográfico de pliegos sueltos poéticos (siglo XVI), Madrid, Castalia, 1970; García de Enterría, María Cruz: Sociedad y poesía de cordel en el Barroco, Madrid, Taurus, 1973.

4 Véanse, especialmente, los trabajos de García Collado, María Ángeles: Los libros de cordel en el siglo ilustrado. Un capítulo para la historia literaria de la España Moderna, tesis doctoral inédita, Universidad del País Vasco, 1997; CÁTEDRA, Pedro M.: Invención, difusión y recepción de la literatura popular impresa (siglo XVI), Mérida, Editora Regional de Extremadura, 2002; así como el estudio pionero de Botrel, Jean-François: Libros, prensa y lectura en la España del siglo XIX, Madrid, Fundación Germán Sánchez Ruipérez, 1993. He dedicado al tema mi tesis doctoral, Menudencias de imprenta. Producción y circulación de la literatura popular en la Valencia del siglo XVIII, Universitat de València, 2011, de próxima publicación. 
y las múltiples vías de divulgación por las que inundó de papeles los caminos y plazas de la España moderna. Romances e historias en prosa, relaciones de comedia y relaciones de sucesos, estampas y gozos, almanaques y aleluyas, col lloquis y entremeses, la diversidad de materiales (textuales e icónicos) que albergaron los humildes pliegos sueltos pretendieron satisfacer la variada gama de intereses y usos que demandaba su público heterogéneo.

¿Incluyeron los impresos del siglo XVIII entre sus numerosos contenidos algunos que hoy podamos vincular con la progresiva construcción de una identidad nacional? Dado que dicho proceso conoce en la centuria ilustrada un impulso decisivo, coincidiendo precisamente con el periodo de mayor volumen productivo de la literatura de cordel en España, podemos preguntarnos si ambos fenómenos se cruzaron en algún momento. Es cierto que, al menos a priori, la conformación de un pensamiento nacional es asunto de elites intelectuales y políticas, alejado del ámbito de "lo popular". ¿Podemos sin embargo entrever reflejos de ese complejo proceso en los papeles impresos que circulaban coetáneamente por las calles, quizá ejerciendo una función de divulgación de las nuevas ideas?

$\mathrm{M}^{\mathrm{a}}$ Victoria López Cordón ha analizado varios aspectos clave que en el siglo XVIII contribuyeron a impulsar la conformación de la idea y el sentimiento de pertenencia a la nación española: ${ }^{5}$ la necesidad de la monarquía borbónica de legitimar su poder sobre nuevas bases (propiciando su identificación con el territorio peninsular), el desarrollo de la historia de España (estudiada, publicada, dramatizada, pintada) y las controversias entre críticos y apologetas de la situación española fomentaron la construcción de "un patrimonio común de referencia". ${ }^{6}$ Centraré mi análisis en los dos primeros factores, analizando de qué manera encontraron acomodo en la literatura popular del XVIII ${ }^{7}$.

\section{Imágenes de la Monarquía}

La propaganda monárquica no era asunto novedoso para los pliegos sueltos del siglo Ilustrado. Desde su aparición en el XVI, las relaciones de sucesos venían divulgando noticias relativas al trono con afán laudatorio. Este abultado conjunto editorial, formado por impresos breves de carácter informativo no periódico ${ }^{8}$, constituyó según Augustin Redondo un instrumento ideológico al servicio del poder

5 López-CORdón, M M Victoria: «De monarquía a nación: la imagen histórica de España en el siglo de la Ilustración», Norba. Revista de Historia, 19 (2006), pp. 151-173.

6 Ibidem, p. 168.

7 El corpus documental en el que se basa este trabajo procede de la obra de Francisco AgUILAR PIÑAL: Romancero popular del siglo XVIII, Madrid, CSIC, 1972; del Catálogo y Biblioteca Digital de Relaciones de Sucesos (s. XVI-XVIII) de la Universidad de La Coruña; y de los fondos valencianos Nicolau Primitiu y José Serrano Morales, ubicados respectivamente en la Biblioteca Valenciana y en el Archivo Histórico Municipal de Valencia.

8 Según definición de Víctor INFANTES: «¿Qué es una relación? (Divagaciones varias sobre una sola divagación», en García de Enterría, M.C., Ettinghausen, H., Infantes, V. y Redondo, A. (eds.): Las relaciones de sucesos en España (1500-1750), Paris/Alcalá, Publications de la Sorbonne/Universidad de Alcalá, 1996, pp. 203-216 (cita en p. 211). 
civil y religioso. ${ }^{9}$ No es, pues, extraño que estos impresos dieran cuenta de coronaciones, nacimientos, enlaces, viajes, entradas en ciudades, ceremonias, exequias y todo acto cuya noticia pudiera contribuir a la alabanza de la monarquía.

Aunque el siglo XVII es considerado el periodo de apogeo de las relaciones de sucesos, que posteriormente conocerían un progresivo declive en favor de la prensa periódica, las relaciones de sucesos "reales" mantuvieron unos altos niveles de publicación con la llegada de la dinastía borbónica. Podríamos decir que la oleada de impresos que anegó España durante los años de la Guerra de Sucesión marcó la pauta posterior. La publicística desatada durante el conflicto hizo uso y abuso de los términos patria y España en favor de los intereses de ambos contendientes, constituyendo de hecho estos "excesos propagandísticos" un factor más en el proceso de construcción de un sentimiento de identidad nacional. ${ }^{10}$ Los romances jugaron su papel en medio de este crecido volumen de impresos. Personajes como Jeromillo de Parla, Perico y Marica, Magdalena la Loca o el Patán de Carabanchel aparecen como narradores recurrentes de los acontecimientos bélicos, en defensa de uno u otro bando, apelando al enemigo para que abandone la empresa. Así, la Relación nueva y curioso romance en que se da cuenta de un consejo que da un leal vasallo de nuestro rey Don Felipe Quinto al señor Archiduque (Sevilla, Francisco de Leefdael, s.a.) presenta la legitimidad de la dinastía Borbón ("no pudo Carlos Segundo / dexar entregada a España / a otro, sino a Felipe, / para que la Governara") y denuncia los excesos de las "Armas Luteranas" ("robando todos los Templos / las Capillas despogadas / que ni aun los vasos Sagrados / no les respetaban nada"). La comparación que establece entre Felipe de Anjou y el Archiduque Carlos con David y Goliat subraya los tintes providencialistas del romance, ejemplo de la mezcla entre política y religión tan característica de la propaganda monárquica de estos años, que pervivirá en los posteriores:

\author{
Digo, que salió David \\ con el Gigante a Campaña \\ $\mathrm{y}$ tan solo con tres piedras \\ con el Monstruo en tierra dava. \\ así comparo a Felipe, \\ con todo el Reyno de España, \\ que soys quatro Reynos juntos \\ que contra él tomáis Armas; \\ $\mathrm{y}$ tan solo con tres piedras \\ vuestro enojo lo avasalla.
}

9 Redondo, Augustin: «Les relaciones de sucesos dans l' Espagne du Siècle d'Or: un moyen privilégié de transmission culturelle», en Redondo, A. (ed): Les médiations culturelles, Paris, Publications de la Sorbonne Nouvelle, 1989, pp. 55-67.

10 López-Cordón, op. cit. (nota 5), p. 157. Sobre la propaganda en la Guerra de Sucesión, véase Pérez Picazo, María Teresa: La publicística española en la Guerra de Sucesión, Madrid, CSIC, 1966; Borreguero BeltrÁn, Cristina: «Imagen y propaganda de guerra en el conflicto sucesorio (1700-1713)», Manuscrits, 21 (2003), pp. 95-132. 
Por el lado austracista, el pliego con las Dézimas a la muerte del sereníssimo príncipe Dermestad, que compuso un rector aficionado suyo (Barcelona, s.l., s.a.) proclamaba la valentía que había insuflado entre el pueblo barcelonés la muerte heroica del landgrave Jorge de Darmstadt, durante la batalla de Montjuic de 1705:

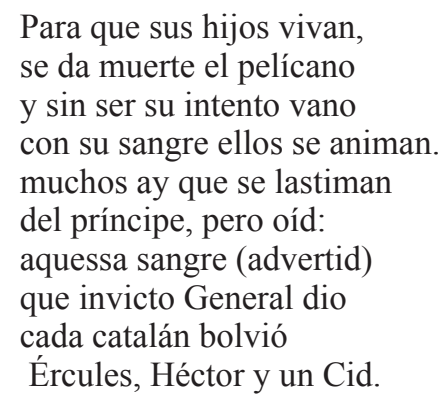

Céline Gilard ha subrayado la asimilación que numerosos pliegos de cordel publicados durante la guerra hicieron de las figuras militares más conocidas, narrando sus victorias como hazañas de guapos y valentones, personajes muy conocidos entre el público de los romances desde el siglo anterior. ${ }^{11}$ Se aprecia en esta transformación (del coronel José Vallejo, del propio Felipe V) un intento por conectar con las expectativas del pueblo llano, por atraerlos hacia la causa mediante esos modelos de héroes populares, en un "arranque de orgullo patrio" 12 muy palpable, por ejemplo, en la comparación que un romance sobre el citado José Vallejo establece entre este y Santiago apóstol:

Este, pues, valiente Alcides,
lustre, y honor de la patria,
imitador valeroso
de nuestro patrón de España,
cuya roxa insinia esmalta
su noble y valiente pecho,
siendo de las luteranas
tropas el terror y assombro,
como ellas mismas declaran. ${ }^{13}$

Los ecos de esta desbordante labor propagandística durante el conflicto sucesorio alcanzaron los últimos años del siglo, y a pesar de los progresos de la prensa periódica, las relaciones de sucesos siguieron constituyendo un importante instrumento de legitimación y afirmación para los primeros Borbones. Todos los actos protagonizados por los monarcas y sus familias fueron recogidos en romances encomiásticos:

11 Gilard, Céline: «Héroes y guapos: la Guerra de Sucesión española en los pliegos de cordel», Revista de literaturas populares, V-2 (2005), pp. 310-331.

12 Ibidem, p. 314.

13 Curioso y nuevo romance en que se expressan las gloriosas hazañas del invencible español don Joseph Vallejo, coronel y brigadier de los exércitos del rey nuestro señor, don Phelipe Quinto, que Dios guarde, s.i., s.l., s.a. 
entronizaciones, matrimonios, nacimientos, entradas en ciudades, defunciones... ${ }^{14}$ Todos ellos persiguieron en mayor o menor grado fomentar el apego hacia la monarquía, identificada con el conjunto de España. Así, una relación sobre los enlaces de los príncipes de España y Portugal permitía al autor subrayar el amor de los súbditos hacia su rey ("En fin, tanto fue el cariño / con que a los reyes obsequian, / que los varios instrumentos, / en armoniosas cadencias, / cada qual en su idioma / repetía con gran fiesta: / Vivan los reyes de España / en tranquilidad perpetua") y reclamar al conjunto del reino similares sentimientos ("Alegraos, Españoles, / de estos lazos que el Rey premia, / si afectos no conocidos, / voluntades manifiestas"). ${ }^{15}$ Similar apelación hacía un romance sobre el Tratado de Viena de 1725 ("dexando / reparos que avían hecho / (...) nuestra España y el Imperio”), cuyos primeros versos se dirigían directamente a la "perseguida ilustre España" como la madre de un pueblo abnegado:

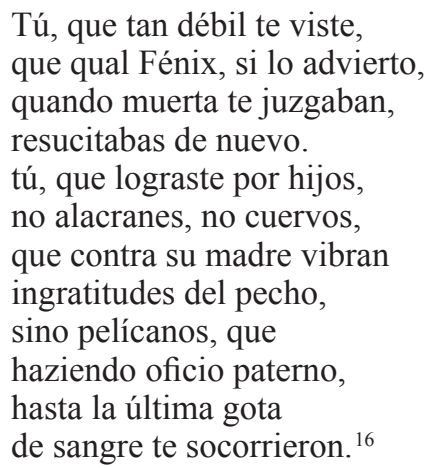

Esta identificación de la nación como madre recorre toda la relación, culminando hacia el final con unos versos exultantes:

Esta, pues, feliz España

fue la tarde, y día pienso

para ti, y para todos

más feliz, y más contento.

(...)

Salve ya viviente madre, salve, salve, y de mi pecho,

en nombre de los demás

recibe el que te prevengo

parabien, que ya te doy,

por tan benigno sucesso.

14 Véanse las numerosas referencias ofrecidas para cada uno de los reinados por AgUILAR PIÑAL, op. cit. (nota 7), pp. 8-45.

15 Descripción verdadera, y puntual noticia de la solemníssima fiesta, alegres regocijos, y festivos aplausos, con que se celebraron los Reales, y deseados casamientos de los señores Príncipes de España, y los Brasiles, en la Ciudad de Badajoz, este presente año de 1729, Sevilla, Viuda de Francisco de Leefdael.

16 Verdadera relación, en que se descrive la grandeza, y magnifica solemnidad, con que se publicaron en esta Coronada Villa de Madrid las Pazes, ajustadas entre el señor Emperador, y nuestro Cathólico Monarca, el día 18 de Julio de este presente año de 1725, Sevilla, Francisco de Leefdael. 
Significativamente, la maternidad de España se traslada en las últimas líneas del romance hacia la monarquía, rogando a Dios el poeta "que a Philipo / a Isabel, $y$ demás tiernos / pimpollos de nuestra España / les des salud, y el acierto / que se necessita, para / mantener esto resuelto" (subrayado nuestro).

De este modo, las relaciones de sucesos no solo amplifican la difusión de los actos de la Corte, sino que glosan su descripción con sucesivas loas hacia los reyes y el conjunto del reino, cuya identidad es presentada así en íntima conexión con el trono. En un romance publicado con motivo de la coronación de Fernando VI se enumeran una serie de consejos para guiar los primeros pasos del nuevo rey, estableciendo un símil entre el gobierno y la caza. El autor culmina la composición afirmando la recíproca estima existente entre el monarca y sus vasallos, la identidad compartida que debe ir consolidándose:

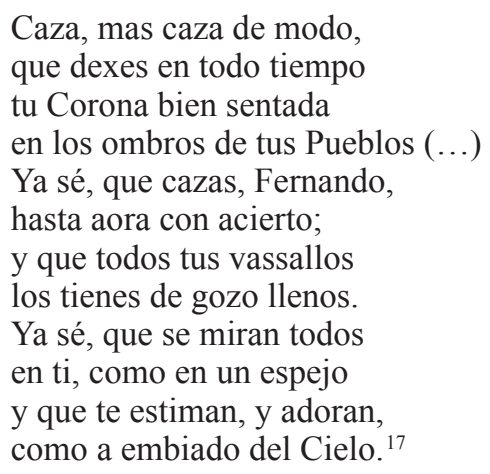

La búsqueda permanente de legitimidad de la nueva dinastía queda también patente en la relación que dio cuenta de las fiestas organizadas en Sevilla en 1729 para celebrar el traslado de los restos de Fernando III, conquistador de la ciudad. ${ }^{18} \mathrm{La}$ ocasión era idónea para presentar a una Casa de Borbón enraizada en la tradición histórica castellana. El romance busca este objetivo a través de tres recursos: en primer lugar, presenta a Felipe V como descendiente de San Fernando ("quiso nuestro gran Phelipe, / que mil años guarde el Cielo, / hacer una Processión / con el Venerable Cuerpo / del Cathólico Fernando, / Rey Santo, su quinto Avuelo, / y ascendiente generoso"); por otro lado, describe el protagonismo de la familia real en la procesión, portando los cordones que pendían de la urna con las reliquias ("ocho personas Reales, / que llevan un Santo Cuerpo; / ¿quién ha visto tal Grandeza? / nadie la ha visto, por cierto"); finalmente, proclama el paralelismo entre las virtudes guerreras en defensa de la fe de Fernando III y las del futuro Fernando VI:

17 El cazador más sabio del católico bosque, apunta en este Romance las experiencias de la Caza Política a su Amado Rey Don Fernando el Sexto, Valencia, Gerónimo Conejos, s.a.

18 Nueva relación, y curioso romance, en que se da noticia de la solemne pompa, y plausible aparato, con que se hizo la Processión del Santo Cuerpo del señor San Fernando, Rey de las Españas, en la Ciudad de Sevilla, el día 14 de Mayo de este año de 1729, con la asistencia de los Reyes, y Príncipes nuestros Señores, y los Señores Infantes, y toda la Grandeza, con el orden, concierto y riqueza que verá el Curioso Lector, Sevilla, Diego López de Haro. 
Celebra, España, tu dicha, pues tienes otro Guerrero Fernando, Príncipe tuyo, que substituya su esfuerzo, y contra infieles y hereges esgrima el brillante acero, contra el hijo de la Luna y su turbante agareno.

La valentía del rey y, en general, de los españoles en el campo de batalla es otro de los motivos recurrentes esgrimidos por las relaciones de sucesos para inflamar el sentimiento de pertenencia nacional. Cuando al valor guerrero se le añade el ingrediente religioso, las proclamas en alabanza de España alcanzan altos niveles de exaltación. El romance sobre la defensa de Ceuta en 1724 celebraba la "victoriosa refriega" con un exultante colofón que dirigía sus loas a la nación, a la religión católica y a la familia real:

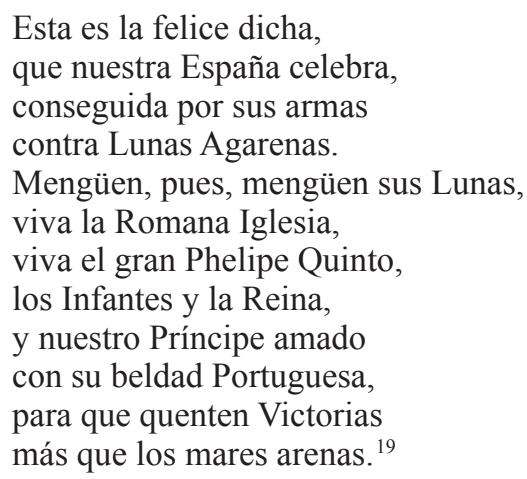

Asimismo, la toma de Orán en 1732 fue objeto de numerosas muestras de orgullo patrio. Merecen destacarse los versos iniciales y finales de la Relación y curioso romance en que se declaran algunas noticias particulares que han sucedido en la toma y restauración de Orán (Sevilla, Viuda de Francisco Lorenzo de Hermosilla). Mientras que los primeros versos apostrofan a España para dedicarle el romance ("A ti, esclarecida España: / a ti, Emporio de nobleza: / a ti, Reino celebrado / de las estrañas Potencias..."), el final de la composición proclama su posición de gran potencia internacional, con un largo ditirambo que elogia las virtudes bélicas y religiosas de la nación:

19 Nueva relación, en un curioso romance, en que da quenta, y declara la Victoriosa refriega, que consiguieron las Armas de nuestro Cathólico Monarcha Don Phelipe Quinto (que Dios guarde) el día 17 de Octubre, contra la Secta Mahometana, que tenían puesto sitio a la Plaza de Zeuta; y del destrozo que hicieron, dando muerte a cinco mil Moros, haviéndose huido el Baxá en camisa, y de los pertrechos de guerra que le cogieron, y entre ellos la Vandera General. Con lo demás que verá el curioso Lector, Sevilla, Diego López de Haro, s.a. 
Gloriate, gloriate, España, y tus timbres manifiesta en tener tus Naturales tan Católicos, que apenas habrá Nación en el mundo, por mui remota que sea, que no confiesse que son (a bien poca diligencia) de la Fe vivas Columnas, siendo tanta la excelencia de tu ilustre Monarquía, que apenas habrá en la esfera de este Globo que habitamos, Reino donde no se estienda (¡o prodigioso portento!) tu dominio.

Esta idea sobre la restauración del poderío español es constante en las relaciones de hechos de armas: la vemos en un romance de 1734 que rememora las últimas victorias de la monarquía ("Gózate, felize España / con tan alternadas dichas / y prospere tus aplausos, / hasta los remotos climas; / publicando las Naciones / que eres ya la que solías" ${ }^{20}$, en la relación sobre la toma de Miranda del Duero en $1762^{21}$ o en la que narra la conquista de Florida en $1781 .^{22}$

Para finalizar con los pliegos sueltos de propaganda monárquica, quiero referirme a dos momentos concretos en los que la exaltación de la realeza como vínculo identitario de los súbditos cobra especial intensidad: la muerte de Luis I y el Motín de Esquilache. Lo insólito de ambos acontecimientos propició un aluvión de impresos enardecidos en defensa de la monarquía. Las relaciones sobre la repentina muerte de Luis I ponen en boca de la nación los lamentos por el fúnebre suceso, exhortando a los súbditos a llorar su orfandad: "Lamenta, España, lamenta, / pues en solo un Luis

20 Nueva relación, y curioso romance en que declara en el feliz estado que se hallan nuestras Tropas en la Italia, cómo han tomado las ciudades de la Mirandula, y Guastala, los Fuertes Puerto Hércules y Orbitelo, haciendo prisioneros de Guerra a mil quinientos Alemanes, los que se conducen a España; los Fuertes Aula y Bruneta, y una Fragata Española apresó otra Imperial cargada de Trigo, y en la imbencible Plaza de Orán se desbarató un Destacamento considerable de Turcos y Moros, que se opusieron a nuestros trabaxadores, quitándoles varias Alaxas, y entre ellas una Bandera que decían era santificada, por tenerla tocada al Zancarrón de Mahoma: sucedió este presente año de 1734, Sevilla, Pedro Joseph Pablo Díaz.

21 Noticia breve y verdadera de la feliz victoria que han conseguido las Cathólicas Armas Españolas contra la Nación Portuguesa en la toma de la Plaza de Miranda el día 9 de Mayo de este presente año de 1762 a causa de haberse pegado fuego al Almacén de la pólvora, arruinándose el Castillo, y contándose de los Enemigos, entre muertos y heridos, hasta el número de novecientos y más de trescientos prisioneros de guerra. Con otras particularidades que verá el curioso lector, Salamanca, Nicolás Villagordo.

22 Noticiosa, verídica, triunfante y victoriosa Relación que declara y da noticia del feliz vencimiento y victorioso aplauso que han tenido las Católicas Armas de nuestro Augusto Monarca el Señor D. Carlos Tercero (q. D. g.) en la restauración de la Plaza de Panzacola, la Florida y otras diferentes que va restaurando la Corona de España a el Rey Británico, todo conseguido a la solicitud y cuydado de los Excelentísimos Señores D. Josef Solano, General de Mar, y D. Bernardo de Gálvez, General de Tierra, sucedido el día 8 de Mayo de 1781, con todo lo demás que verá el curioso en esta Primera parte, Sevilla, Josef Padrino. 
Primero / todas tus dichas gozabas, / y sin él tendrás anhelos"23, "Dios, por su misericordia, / España te de su alivio, / y remedio a tanta pena / como padecen tus hijos" 24 . De especial interés son los Amantes lamentos, tiernas y amorosas lágrimas de la Reyna nuestra Señora, a la sentida y temprana muerte de su Esposo el Rey nuestro Señor Son Luis Primero (Sevilla, Diego López de Haro), por su especial intensidad al buscar repetidamente la empatía de los súbditos con respecto a la reina, que narra el romance en primera persona: "tomen de mi exemplo todas / las Reynas de nuestra España, / las doloridas viudas, / y mis leales Vasallas", "lloren conmigo sentidas / quantas racionales planas / Españolas le juraron / por su Rey, y su Monarca", "España, llora a tu Rey, / llora, España, tu Monarca".

La situación generada por el Motín de Esquilache era muy distinta. La monarquía había sido sacudida en sus cimientos, superada por una sublevación popular que había puesto en cuestión (siquiera por unos días) el orden establecido. Sofocado el motín, la labor de los papeles impresos sería, por un lado, eliminar del suceso toda implicación política, reduciéndolo a una protesta popular a causa del precio de los alimentos, y destacar sobre todo la figura paternal del monarca, dispuesto al perdón frente al alboroto de sus díscolos súbditos. En este sentido, quiero destacar por su singularidad un romance firmado por Antonio Valladares de Sotomayor al poco de haber terminado el motín. ${ }^{25} \mathrm{Su}$ relevancia deriva de la capacidad demostrada por el autor para utilizar el momento de crisis vivido como excusa para exaltar las virtudes de Carlos III, la armonía entre el rey y sus súbditos y, todavía más, el vínculo identitario establecido entre la monarquía y el conjunto de la nación. Desde los primeros versos se proclama la pertenencia del pueblo al monarca, su voluntaria sumisión bajo su cobijo ("Invictíssimo Señor, / augusto Carlos Tercero, / nuestro Padre, nuestro Rey, / nuestro amadíssimo Dueño, / nuestro Norte, nuestro efugio, / pues todo, todo sois nuestro") dado el afecto paternal demostrado por Carlos III al ordenar la bajada de los precios ("todo se baxó, y los pobres / con esta baxa subieron (...) / subieron hasta gozar / vuestros afables reflexos, / porque un gran Rey, como el Sol / luce, brilla, alumbra al Pueblo"). La exhortación a los "españoles pechos" y a la "lealtad española" para rendirse a la generosidad del rey culmina con una última alabanza hacia la Corona, presentada como nave, norte, sol y sombra que acoge en su seno a todos sus hijos.

23 Índices expressivos, del más singular afecto, sentidas vozes, en que prorrumpe la lealtad; continuados lamentos de cariño; tristes ayes del dolor; mal explicados alientos, en que el amor fino se demuestra; y frases, que el balbuciente labio profiere, en la sentida, quanto fatal muerte, del más fragrante clavel del Pensil Español, el magnánimo, ínclito, y sin segundo, Don Luis Primero (que Dios tiene) Catholicíssimo Rey de España, y Atlante de dos Mundos, s.i., s.l., s.a.

24 Lastimosas glossas de el sentimiento que ha hecho esta Monarquía de España por el rey D. Luis Primero, por cuya muerte ha sentido la Española lealtad, se expressa el despedimiento que hizo de su Padre, y de su amada Esposa y Hermano, como verá el curioso Lector, s.i., s.l., s.a.

25 Valladares De Sotomayor, Antonio, Verdadera, y gloriosa relación, que expressa las rendidas reverentes gracias que a nuestro augusto, benignísimo, Cathólico Monarcha, y Señor D. Carlos Tercero, (que Dios guarde) dan sus Vassallos de esta Corte, por la regia, soberana piedad que con ellos usó en perdonarles el ruido que fomentaron, pidiendo a su Magestad la baxa del Pan, y demás víveres, como lo concedió su nunca bien celebrada Real clemencia, con otras circunstancias dignas de oirse, Madrid, Joseph Francisco Martínez Abad, 1766. Madeline SutHeRLAND ha analizado recientemente este texto en «Antonio Valladares de Sotomayor and the motín de Esquilache», Dieciocho. Hispanic Enlightenment, 32.1 (2009), pp. 101-122. 


\section{Tradición e Historia Nacional}

Junto al papel jugado por la monarquía borbónica en la construcción de una identidad común en España, los progresos que a lo largo del siglo XVIII experimentó el estudio de la historia contribuyeron también a este proceso. Los escritos y polémicas sobre la historia de España, su introducción en las escuelas a través de compendios y manuales y la recomendación de Carlos III de incluirla en los planes de estudios de primeras letras, fueron factores que permitieron ir configurando una serie de ideas e hitos compartidos sobre el pasado. Según López-Cordón, "lo cierto es que la historia de España empezó a conocerse de manera más sistemática y que su tímida entrada en el sistema escolar empezó a proporcionar un relato esquemático, pero coherente, de un pasado colectivo que quedaba identificado con determinados personajes y acontecimientos". ${ }^{26} \mathrm{El}$ recurso a esos personajes y episodios por parte de la literatura y el arte permitió dar mayor difusión al relato en construcción.

Me interesa subrayar este último punto. Si la historia patria fue recogida en la literatura dramática por autores como Montiano, Jovellanos, Cadalso, López de Ayala o Nicolás Fernández de Moratín, contribuyendo a su consolidación, ¿pudo jugar la literatura de cordel un papel similar, aunque a otro nivel, difundiendo episodios y personajes históricos entre su numeroso público?

La respuesta es sí. Los pliegos sueltos del siglo XVIII incluyeron, entre la multitud de temas absorbidos por el género, fragmentos sobre la historia de España, que pasaron así a ser patrimonio compartido de un inmenso número de lectores y oyentes. Algunos forman parte de la tradición del romancero, remontándose sus orígenes a tiempos medievales: es el caso de los Famosos Romances de el Cid Campeador (Córdoba, Rafael García Rodríguez, s.a.) o del Curioso Romance en que se da cuenta de los valerosos hechos de Bernardo del Carpio (Córdoba, Rafael García Rodríguez, s.a.). Algunos hitos de la Reconquista son también recogidos por los pliegos sueltos, sea la conquista de Sevilla ${ }^{27}$, las hazañas de Garcilaso frente al Moro $\operatorname{Tarfe}^{28} \mathrm{o}$ de Hernán Pérez del Pulgar en la guerra de Granada ${ }^{29}$. Varios romances ponen en verso otros episodios bélicos de la tradición histórica, entre los que merece un lugar privilegiado la batalla de Lepanto: los tres romances de Antonio de la Fay siguen publicándose en el siglo XVIII, pero otras versiones de "la batalla naval" son impresas por Francisco de Leefdael o por Rafael García Rodríguez. ${ }^{30}$ Asimismo, títulos como

\footnotetext{
26 López-Cordón, op. cit. (nota 5), p. 161. Sobre esta cuestión, véase también el trabajo de Joaquín Álvarez Barrientos: «Nación e historia literaria a mediados del siglo XVIII en España», en Romero ToBAR, L. (ed.), Historia literaria/ Historia de la literatura, Zaragoza, Universidad de Zaragoza, 2004, 101-114.

27 Nuevo y curioso Romance, en que se refiere por extenso la recuperación de la muy Noble y muy Leal Ciudad de Sevilla, con las circunstancias que verá el curioso Lector, Valencia, Agustín Laborda, s.a; La toma de Sevilla por el Santo Rey Don Fernando, Córdoba, Rafael García Rodríguez, s.a.

28 Relación verdadera, que contiene el triunfo del Ave María y batalla que tuvo Garcilaso en la vega de Granada con el Moro Tarfe, y lo demás que verá el curioso Lector, Valencia, Agustín Laborda, s.a.

29 Don Fernando del Pulgar. Relación verdadera de los arrestos y valentías de este esforzado caballero, que puso en la mezquita de Granada, quando era de moros, el Ave María, Córdoba, Fausto García Tena, s.a.

30 Tres romances, en la memorable y triunfante victoria que tuvieron las Armas de la Católica Liga, comandadas por el Señor Don Juan de Austria, contra la Armada Turquesa, en el Golfo de Lepanto, a siete de octubre del año mil quinientos setenta y uno, Valencia, Agustín Laborda, s.a.; Historia verdadera de la batalla naval que el Sereníssimo Príncipe Don Juan de Austria dio al Gran Turco, en la qual se hallarán los mejores
} 
el Testamento del Sereníssimo Señor Don Juan de Austria o los Siete romances de Don Rodrigo Calderón ponen estos y otros episodios históricos al alcance del "curioso lector". Finalmente, el mundo de las menudencias de imprenta conoce también sus compendios sobre la historia de España, en los que se ofrecen sistemáticamente personajes y acontecimientos: el Cathálogo general, enchiridion de noticias particulares, que han sucedido en toda España, y otras partes, desde la Creación del Mundo hasta fin del año 1731 (Barcelona, Ángela Martí, 1732) ofrecía una síntesis histórica de 40 páginas, logro que se queda en nada al compararlo con la "hazaña" del Compendio histórico, de las cosas más memorables, que han sucedido en España, desde que Dios crió el mundo, hasta nuestros tiempos (Barcelona, Francesc Guasch, 1716), que en tan solo 8 páginas cubría un período que iba desde el 5199 a.C. hasta la actualidad de 1702.

No es inverosímil que la difusión de episodios de la historia nacional mediante el soporte de los pliegos sueltos no fuera vista con malos ojos por las autoridades civiles, por más sospechas que pudiera generarle la literatura de cordel en su conjunto, siempre potencialmente subversiva y siempre indócil frente a la legislación de imprenta. Que el pueblo conociera, aunque deficitariamente, ciertos pasajes y personajes del pasado común no se alejaba de las propuestas hechas por numerosos ilustrados sobre la conveniencia de dar a conocer la historia de España por medios diversos. Así, Tomás de Iriarte afirmaba en la introducción de sus Lecciones de Historia de España que "todos estamos obligados a saber la Historia de nuestra Patria, pero no todos con igual extensión y puntualidad". ${ }^{31}$ Y Miguel Antonio de la Gándara, en Apuntes sobre el bien y el mal de España (obra encargada por Carlos III), se refería a la necesidad de que el teatro contribuyera a la formación histórica y patriótica de su numeroso público:

para las representaciones públicas de nuestros teatros se escribirán comedias nuevas, arregladas a todos los preceptos del arte, purgadas de todo defecto; y que tengan por argumento preciso las virtudes y acciones más heroicas de nuestros incomparables Españoles antiguos, al ayre de la de Carlos Quinto sobre Túnez, a fin de que se impriman en el tierno corazón de la juventud aquellas mismas ideas de religión, de honor, de valor y de heroísmo, que admirarán en sus ínclitos abuelos. (...) Así se enseñarán a todos insensiblemente los pasages más interesantes de nuestra historia, y se inflamarán sus ánimos de un espíritu heroico y valeroso. ${ }^{32}$

Aunque alejadas de "los preceptos del arte", las composiciones de contenido histórico difundidas en pliegos de cordel contribuyeron a la divulgación de algunos de esos pasajes, probablemente con la aquiescencia del juzgado de imprentas. Esta última afirmación vendría avalada por la similar permisividad mostrada por la censura hacia

Romances que sobre ella se han hecho, Sevilla, Francisco de Leefdael, s.a.; La batalla naval que el Señor Don Juan de Austria tuvo con la Armada del Gran Turco. Carta con la nueva de la victoria. Presente que el Gran Turco le envió, y respuesta del Señor Don Juan, Córdoba, Rafael García Rodríguez, s.a.

31 De IrIARTE, Tomás: Lecciones instructivas sobre la historia y la geografía, Madrid, Imprenta Real, 1794, t.II, p. 45.

32 De la Gándara, Miguel Antonio: Apuntes sobre el bien y el mal de España, escritos de orden del Rey, en Almacén de frutos literarios inéditos de los mejores autores españoles, Madrid, Viuda de López, 1820, t. I, pp. 253-254. 
un último grupo de pliegos de cordel que también dieron cabida entre sus temas a la "historia nacional". Se trata de las historias o libros de cordel.

Con este término se conoce a un reducido grupo de novelas cortas que, tomando sus argumentos de la literatura caballeresca, la literatura sentimental y la cuentística medieval, continuaron imprimiéndose desde finales del siglo XV hasta principios del XX, enriqueciendo su corpus con el tiempo, especialmente en el siglo XIX ${ }^{33}$ De extensión algo mayor que los romances (entre las 12 y las 32 hojas), las historias constituyen un característico conjunto de relatos en prosa dentro del género de cordel. Entre 1480 y 1530 apareció el definido grupo de las historias caballerescas breves, empleando la terminología acuñada por Víctor Infantes y Nieves Baranda. ${ }^{34}$ Se trata de veinte novelas que, procedentes mayoritariamente de poemas épicos franceses (son traducciones o adaptaciones), tienen como rasgo común su origen medieval (siglos XIII-XV): Historia del rey Canamor y del infante Turián su hijo, Historia del emperador Carlomagno y los Doce Pares de Francia, Historia de Clamades y Clarmonda, Crónica popular del Cid, Historia de la Doncella Theodor, Crónica del conde Fernán González, Historia de Enrique Fí de Oliva, Historia de los dos enamorados Flores y Blancaflor, Crónica del rey Guillermo, Historia de la linda Magalona y el caballero Pierres de Provenza, Historia de Oliveros de Castilla y Artús de Algarve, Historia de Paris y Viana, Libro del caballero Partinuplés, Libro del infante don Pedro de Portugal, Historia de la Ponzella de Francia, Roberto el Diablo, Historia de la reina Sebilla, Libro de los Siete Sabios de Roma, Crónica de Tablante de Ricamonte y Jofré, Historia del noble Vespasiano. ${ }^{35}$

La fortuna de estos títulos fue dispar. Tras un primer período de ajuste, algunas de ellas se dejaron de editar enseguida (Paris y Viana, Vespasiano y la Crónica del rey Guillermo) y otras (Canamor, Enrique Fí de Oliva y la Reina Sebilla) no traspasaron el umbral del siglo XVII. Por el contrario, el resto del repertorio siguió vigente, con cambios y actualizaciones, hasta el siglo XIX. A este núcleo primitivo se le fueron añadiendo títulos con el paso del tiempo: así, en un catálogo del impresor Antonio Sanz, de 1751, se incluía un "surtido de historias" en el que a las tradicionales se añadían las historias De la Passión de Christo, De Francisco Estevan, De Bernardo del Carpio, Del Marqués de Mantua y De la Batalla Naval.

Precisamente fue un episodio relacionado con Antonio Sanz el que nos permite referirnos aquí a las historias. En 1757 el juez de imprentas Juan Curiel inició un proceso contra este impresor por imprimir sin licencia este conjunto editorial. Como consecuencia de ello, la impresión de las historias fue prohibida en todo el reino por considerarlas la censura "un tejido de patrañas, amores, revelaciones, visiones y milagros". ${ }^{36}$ Aprove-

33 LOPEZ, François: "Notes sur le fonds ancien des recits en prose dans la "literatura de cordel"», en Les productions populaires en Espagne 1850-1920, Paris, Centre National de la Recherche Scientifique, 1986, pp. 9-23; BARAnda, Nieves: «Las historias caballerescas breves», Anthropos, 166/167 (1995), pp. 47-50; un análisis exhaustivo del género de las historias en GARCía Collado, op. cit. (nota 4), pp. 157-229, y centrándose en el siglo XVIII, pp. 231-480.

34 INFANTES, Víctor: «La narración caballeresca breve», en LACARRA, María Eugenia (ed.), Evolución narrativa e ideológica de la literatura caballeresca, Bilbao, Universidad del País Vasco, 1991, pp. 165-181; en el mismo volumen, BARANDA: «Compendio bibliográfico sobre la narrativa caballeresca breve», pp. 183-191.

35 Edición facsimilar de todas ellas en Baranda (ed.): Historias caballerescas breves del siglo XVI, Madrid, Turner, 1995.

36 El proceso es analizado en Lopez: «Antonio Sanz, imprimeur du roi et l'édition populaire sous l'ancien régime», Bulletin Hispanique, 95:1 (1993), pp. 349-378. 
chando la prohibición, Manuel Martín, otro impresor de Madrid, publicó entre 1767 y 1768 una nueva Colección de varias historias, así sagradas como profanas, de los más célebres héroes del mundo, y sucesos memorables del orbe, con cuyos 40 títulos pretendía cubrir el vacío dejado por las historias prohibidas. ${ }^{37}$ Para marcar distancias respecto a estas y ganarse el favor de los censores, Martín insistió repetidamente en la utilidad de su colección, frente a los "desvaríos" de la anterior: "haber sido mi fin lo mismo que expresa el Censor de que sirvan para la gente sencilla y pobre que no pueden comprar libros y tengan en qué emplear los ratos de ociosidad, en lugar de aquellas apócrifas que V. A. mandó privar de Roldán, [y] Oliveros", y "mi intención no se dirige a otro fin, que a que te divierta algunos ratos, y asimismo te edifique, y doctrine". ${ }^{38}$

El interés que ofrece aquí la obra de Martín, muy supervisada (insistamos en ello) por la censura, radica en que inclúa varios títulos relativos a la historia de España. Es más, títulos que habían sido prohibidos por la orden de 1767 fueron rescatados por Martín sin reticencia alguna de las autoridades censoras, y curiosamente, todos ellos versaban sobre personajes de la historia patria (caso de las historias Del Conde Fernán González, De Bernardo del Carpio, Del Cid Campeador). La condescendencia mostrada precisamente hacia estos títulos sería, decíamos, un indicio más de la posible satisfacción con que el poder civil contemplaba la contribución de la literatura popular en la difusión de la historia nacional. Las historias de Martín, cuya mayor extensión y complejidad narrativa requerían una competencia lectora superior a la de los romances y relaciones, se dirigían a un público lector con una cierta capacidad económica e intelectual. No obstante, la insistencia en subrayar "las acciones más heroicas de nuestros incomparables Españoles antiguos" es similar a la mostrada por los romances. Baste como ejemplo la Historia verdadera de la pérdida y restauración de España, por D. Pelayo y D. García Ximénez de Aragón, que narraba las hazañas de don Pelayo para "tomar venganza de los agravios hechos a la nación Española" tras la conquista musulmana, presentada como una afrenta a la patria:

Mas nada fue bastante para no quedar vencidos los nuestros, y el Moro triunfante. Día el más infeliz para España, quedándose desde entonces perdida, despobladas sus Ciudades, cautivos sus hijos, saqueadas sus riquezas, vueltas en llanto sus glorias, desdorados sus blusones, la Religión por el suelto, la Fe Cristiana extinguida, muertos sus Ministros, deshechos sus Santuarios, y derribadas sus Iglesias.

Por el contrario, la Reconquista era considerada por este texto una gran gesta de la historia española: "ninguna Nación puede gloriarse de haber conseguido tantos triunfos en toda la larga carrera de los Siglos, como la nuestra logró en ocho que se gastaron en la total expulsión de los Moros". ${ }^{39}$

37 García Collado, op. cit (nota 4), pp. 371-450.

38 Ibidem, pp. 377 y 398.

39 Martín, Manuel Joseph: Historia verdadera de la pérdida y restauración de España, por D. Pelayo y D. García Ximénez de Aragón. Sacada de D. Rodrigo, Morales, Pisa, Juliano y varios manuscritos antiguos, Madrid, Manuel Martín, 1780, pp. 20, 10 y 31. 
Con registros dispares y títulos heterogéneos, romances, historias y demás impresos breves divulgaron pasajes y personajes de la historia de España, como a un nivel superior lo hicieron los compendios de Buffier, Duchesne o Iriarte.

\section{¿Dirigismo ideológico a través de los pliegos sueltos?}

Dados los indicios sobre la indulgencia que la censura pareció mostrar hacia las historias y romances relativos a la historia nacional, que se suman al aluvión de relaciones de sucesos en alabanza de la monarquía que conoció el siglo XVIII, podemos preguntarnos si existió ciertamente un interés consciente por parte del poder político para utilizar estos textos de amplia difusión como cauces de fomento de un sentimiento de pertenencia nacional. La idea no es nueva: han sido numerosos los autores que han atribuido a la literatura popular impresa un carácter eminentemente ideológico, portadora de mensajes alienantes o coercitivos que las elites sociales buscarían divulgar para aherrojar la conciencia del pueblo. Robert Muchembled aplicó esta interpretación a la Bibliothèque bleue, que desde el XVII hizo circular por toda Francia un considerable número de libros de saldo, de tosca composición y venta ambulante. Según Muchembled, estos libros azules tendrían una "falsa apariencia de cultura popular", pues serían en realidad un instrumento en manos del Estado para desplegar un proceso de aculturación con nuevos valores religiosos y políticos. ${ }^{40}$ Dicho esquema interpretativo ha sido empleado también con la literatura de cordel en diversos estudios: según Diego Catalán, desde finales del siglo XVI los pliegos sueltos no serían sino "vehículo de los intereses de las elites y de los esquemas ideológicos dominantes", ${ }^{41}$ afirmación similar a la hecha por Augustin Redondo con respecto a las relaciones de sucesos, "utilisées comme un moyen de médiation culturelle à grande échelle permettant de faire passer un message idéologique et d'influencer une opinion publique naissante". ${ }^{42}$ Por su parte, Wlad Godzich atribuye a los pliegos sueltos una recepción acrítica por parte de las masas, que absorberían sin más los contenidos ideológicos de los impresos, entendidos como "un instrumento más de la campaña de propaganda emprendida para consolidar los intereses monárquico-nobiliarios en un tiempo en el que se consideraba que el mundo estaba patas arriba y la percepción de la crisis y la decadencia era un lugar común entre los grupos de poder y la intelectualidad que los servía". ${ }^{43}$

Se entiende así que los pliegos sueltos formarían parte de una estrategia más amplia de aculturación dirigida por las elites religiosas y políticas, constituyendo un claro ejemplo de dominación "desde arriba". Desde esta perspectiva, sería fácil concluir que los romances, relaciones e historias analizados en estas páginas fueron ciertamente piezas de una maniobra de control ideológico por parte de las autorida-

40 Muchembled, Robert: Culture populaire et culture des élites dans la France moderne (XVe-XVIIIe siècle), Paris, Flammarion, 1978.

41 Catalán, Diego: "El romance de ciego y el subgénero "romancero tradicional vulgar"», en Arte poética del romancero oral. Parte $1^{a}$. Los textos abiertos de creación colectiva, Madrid, Siglo XXI, 1997, p. 332.

42 Redondo, op. cit. (nota 9), p. 58.

43 Godzich, Wlad: Teoría literaria y crítica de la cultura, Madrid, Cátedra, 1998, p. 112. 
des civiles, que buscarían cohesionar a la sociedad española mediante la construcción, por medios diversos, de un sentimiento de pertenencia nacional.

Sin embargo, esa interpretación de los pliegos sueltos como vehículos de propaganda en manos de las elites sociales y políticas se contradice con las continuas censuras, prohibiciones y críticas que esas mismas elites lanzaron contra sus contenidos, tenidos por perniciosos y en ocasiones subversivos. La legislación de imprenta prestó atención, desde sus orígenes, a los papeles menudos, pero fue precisamente en el siglo XVIII cuando sus esfuerzos por controlar eficazmente la producción y difusión de pliegos sueltos se redoblaron: se sucedieron las órdenes sobre la prohibición de imprimir papel alguno, "por insignificante que fuera", sin contar con la preceptiva licencia $(1722,1728,1735,1741,1748,1749,1797)$; la celosa labor del juez de imprentas Juan Curiel a mediados de siglo afectó a la producción y circulación de pliegos sueltos; en 1767 Carlos III promulgaba la real cédula que prohibía la impresión de pronósticos, piscatores, romances de ciegos y coplas de ajusticiados, por considerarlos "de ninguna utilidad a la pública instrucción"; y por último, la Inquisición se interesó también por la literatura de cordel: en 1755 prohibió los "romances de milagros no aprobados por el legítimo superior", en 1766 los papeles relativos al Motín de Esquilache y a la expulsión de los jesuitas, y en su Índice General de los Libros Prohibidos figuraron títulos como la Historia de la Doncella Teodor, la Historia de los siete sabios de Roma, o los romances de Santa Bárbara, la Virgen de Caravaca, la de los Desamparados, la de Guadalupe, la Pasión, el Corpus... ${ }^{44}$ Esta manifiesta hostilidad del poder político hacia la literatura de cordel matiza, cuando no invalida, la interpretación que la identifica como instrumento en manos de los grupos hegemónicos. Más aún si tenemos en cuenta la conocida animadversión que las elites ilustradas, partícipes de ese proceso de construcción nacional, sentían hacia romances y demás menudencias. Campomanes denunciaba que estos producían "en los rudos semilla de delinquir, y de hacerse baladrones, pintando como actos gloriosos las muertes, robos, y otros delitos, que los guiaron al suplicio", Marchena criticaba los romances que "andaban de boca en boca de toda la plebe" celebrando "las proezas de los salteadores de caminos, presentando por dechado a una mocedad infatuada y pobre la vida de unos miserables que a poder de robos y asesinatos paraban en un patíbulo", e Ignacio Luis de Aguirre veía en ellos signos de la decadencia española ("cuando una nación pierde sus costumbres, trueca las ideas de la virtud y el vicio, y cree que es valor y heroicidad lo que es delito y bajeza"). ${ }^{45}$ Los testimonios ilustrados contra la literatura

44 De los Reyes Gómez, Fermín: Legislación y censura del libro en España y América (siglos XVXVIII), Madrid, Arco Libros, 2000; del mismo autor: «Los impresos menores en la legislación de imprenta (siglos XVI-XVIII)», en Sagrario López Poza y Nieves Pena SueIro (eds.), La fiesta. Actas del II Seminario de Relaciones de Sucesos, Ferrol, Sociedad de Cultura Valle Inclán, 1999, pp. 325-338; GonzÁlez Palencia, Ángel: El sevillano don Juan Curiel, Juez de Imprentas, Sevilla, Reales Academias Española de la Historia y Sevillana de Buenas Letras/Diputación Provincial, 1945; García Blanco, Manuel: «Unos romances del siglo XVIII prohibidos por la Inquisición», Revista de filología española, 28 (1944), pp. 466-470; la cédula de Carlos III en Novísima recopilación de las leyes de España, libro VIII, título XVIII, ley IV.

45 Campomanes, Pedro Rodríguez, Conde de: El fomento de la industria popular. La educación popular de los artesanos, textos presentados por Gonzalo AnEs, Oviedo, Gea, 1991, p. 176; Aguilar Piñal, op. cit. (nota 7), p. XV. 
de cordel son numerosos, pero sin duda entre ellos destaca el desarrollado por Juan Meléndez Valdés en su Discurso sobre la necesidad de prohibir la impresión y venta de las jácaras y romances por dañinos a las costumbres públicas. ${ }^{46}$ En este conocido texto, Meléndez Valdés lamentaba el "indecente oprobio del gusto y la razón" y los "males gravísimos que causa entre la gente tal género de escritos". Los términos empleados para describir tales impresos eran feroces:

Reliquias vergonzosas de nuestra antigua germanía y abortos, más bien que producciones de la necesidad famélica y la más crasa ignorancia (...). Son sus temas comunes guapezas y vidas mal forjadas de forajidos y ladrones, con escandalosas resistencias a la justicia y sus ministros, violencias y raptos de doncellas, crueles asesinatos, desacatos de templos, y otras tales maldades, que, aunque contadas groseramente y sin entusiasmo ni aliño, creídas cual suelen serlo del ignorante vulgo, encienden las imaginaciones débiles para quererlas imitar, y han llevado al suplicio a muchos infelices. O son historietas groseras de milagros supuestos y vanas devociones, condenados y almas aparecidas, que dañando la razón desde la misma infancia con falsas e injuriosas ideas de lo más santo de la religión y sus misterios, de sus piadosas prácticas y la verdadera piedad, la hacen el resto de la vida supersticiosa y crédula. O presentan, en fin, narraciones y cuentos indecentes, que ofenden, a una, el recato y la decencia pública, corrompen el espíritu y el corazón, y dejan, sin sentirlo en uno y otro, impresiones indelebles, cuyos funestos resultados ni se previeron al principio, ni acaso en lo futuro es dado el reparar aun a la atención más cuidadosa. ${ }^{47}$

El discurso de Meléndez tiene un especial interés para el tema que nos ocupa, pues su origen fue el proceso abierto precisamente por la impresión y venta de las Nuevas coplas en alabanza de nuestra España, de la guerra que ha comenzado. ${ }^{48}$ Es decir, un pliego suelto que bien podríamos haber clasificado entre los romances y relaciones de contenido nacional. Publicadas en 1797, en el contexto de la guerra contra Inglaterra, las Coplas proclamaban el valor de los soldados españoles ("todas las Tropas de España, / bien aguerridas están") frente a la vileza británica ("el inglés siempre discurre / a quién la puede pegar, / que es como ave de rapiña, / nadie de él puede fiar"), vaticinaban los éxitos militares que estaban por venir ("nuestra España ha puesto sitio / rodeando a Gibraltar / por más Gibraltar que sea / a España se ha de entregar”), e infundían ánimos a la nación anunciando la gloria que le aguardaba:

46 Sobre el discurso de Meléndez, véase GonzÁLez PALENCIA: «Meléndez Valdés y la literatura de cordel», en Entre dos siglos, Madrid, CSIC, 1943, pp. 183-211; CAntos Casenave, Marieta: «Doña Elvira y la dignificación del romance en el siglo XVIII», en Jesús Cañas Murillo, Miguel Ángel Lama y José Roso Díaz (eds.), Juan Meléndez Valdés y su tiempo, Mérida, Editora Regional de Extremadura, 2005, pp. 151-161; en el mismo volumen, Álvarez Barrientos: «Poesía popular e imagen nacional, según Meléndez Valdés», pp. 305-316; y Roso Díaz, José: «Literatura y reforma de la educación: el Discurso contra las jácaras y romances vulgares de Meléndez Valdés», pp. 355-377.

47 Meléndez Valdés, Juan: Obras completas, edición de Antonio Astorgano, Madrid, Cátedra, 2004, p. 1095.

48 Archivo Histórico Nacional (AHN), Consejos, Legajo 1752, Exp. 4. 


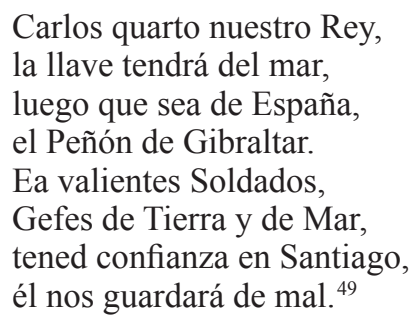

Sin embargo, a pesar de sus apelaciones patrióticas, la obra fue prohibida de modo fulminante en cuanto el Consejo de Castilla tuvo noticia de su venta por las calles de Madrid, abriéndose además una investigación sobre su autoría y publicación:

Al Consejo se ha dado noticia de que por los ciegos se cantan y venden las nuebas coplas, de que acompaño el adjunto impreso, en alabanza de nuestra España de la guerra que ha comenzado. Y en su inteligencia, ha acordado por decreto de este día que la Sala disponga que inmediatamente se recojan dichas coplas, que aperciba a los ciegos que si desde el requerimiento vendieren algún ejemplar, se procederá contra ellos a lo que hubiere lugar que indique quién es el autor de dichas coplas; dónde se han impreso y por quién se ha dado la licencia, recogiendo del impresor, librero o persona en que se hallasen todos los exemplares que tubieren y remitiéndolos al Consejo con su informe de lo que se la ofreciere y pareciere con la mayor brevedad (fols. 2-2v).

El Consejo encontraba las coplas "perjudiciales a la juventud e indecorosas a la Nación". El discurso fiscal pronunciado al respecto por Meléndez Valdés no llegaba tan lejos y presentaba el romance como un mero disparate que no merecía mayor atención por parte de las autoridades:

El fiscal no ve en las coplas ni sentencia, ni palabra, ni cosa alguna que pueda ofender al más escrupuloso, sino lo ridículo y miserable de todas ellas: son tan necias y sandias, que entre quantas venden los ciegos de toda España ningunas se hallarán que lo sean tanto, o al menos que las excedan, y por lo mismo, es poco digno de la sabiduría del Consejo y la Sala detenerse por más tiempo en cosas tan pequeñas (fol $32 \mathrm{v}) .^{50}$

Según Meléndez, lo que demostraba la publicación de semejante desvarío era la necesidad de aplicar el mismo rigor que las autoridades habían mostrado hacia las Nuevas coplas con el conjunto de los pliegos de cordel: "prohibir de una vez tanto romanzón y coplas indecentes y perjudiciales como se venden en cien y cien puestos por toda la Nación, en ofensa del buen gusto y las costumbres" (fol 33).

Sin embargo, el fiscal no se quedó ahí. A la denostación hacia coplas y romances le siguió su propuesta de emplear precisamente el soporte de los pliegos sueltos para difundir "los inmortales hechos y la fidelidad y la honradez de nuestros venerables abuelos". Este punto es de gran interés para el tema que nos ocupa: Meléndez abo-

\footnotetext{
49 En el citado expediente se conservan varios ejemplares de las Coplas en alabanza de nuestra España.

50 Este discurso leído por Meléndez Valdés el 10 de junio de 1798 es distinto del que se publicó posteriormente. Remito para el primero al citado expediente y para el definitivo a las Obras Completas de Meléndez editadas por Antonio Astorgano.
} 
mina de la literatura de cordel que venía publicándose hasta entonces, negando, por tanto, que hubiera contribuido en modo alguno a la construcción nacional. Y todavía más: propone precisamente para este fin el uso de este tipo de composiciones (reconociendo implícitamente su extraordinaria eficacia de difusión), adaptadas por supuesto a los principios del buen gusto y la utilidad pública. La historia nacional nutriría de episodios y personajes estos nuevos romances "verdaderamente españoles":

El heroico despecho de Numancia, el ínclito infante Don Pelayo, el religioso don Ramiro, la memorable toma de Sevilla, la gran victoria de las Navas, el defensor de Tarifa Alonso Pérez de Guzmán, la heroína de la castidad María Coronel, el vencedor de México y Otumba, nuestro patrón glorioso Santiago, el santo labrador Isidro y otros infinitos argumentos ofrecen materia abundantísima para canciones y romances verdaderamente españoles, en que aprendamos, entre el hechizo de los versos, las hazañas que los glorificaron para saberlas imitar. ${ }^{51}$

Los romances del siglo XVI y de épocas anteriores habían cumplido esta misión, según Meléndez, formando "aquel carácter heroico y patriota a que debimos tantas victorias y gloriosas virtudes". Similares resultados podían obtenerse ahora sustituyendo unas composiciones por otras, imitando tanto ese ejemplo del pasado nacional como los ofrecidos contemporáneamente por países como Francia y Prusia, que "han sacado altísimas ventajas de unas poesías y canciones cual yo propongo aquí":

Así que los mismos que con necio entusiasmo cantan y recitan las coplas que censuro, aprenderán sin duda con indecible más gusto en romances sencillos, dictados por las musas y el patriotismo, mil hechos de armas y virtudes domésticas que los llenarán de útil emulación, alentándolos noblemente a imitar sus mayores, y seguir sus inmortales huellas en la carrera de la heroicidad (p. 1099).

Finalmente, el fiscal recomendaba al gobierno alentar la creación de "romances, canciones, y aun cartillas y libros verdaderamente nacionales" (p. 1100) con premios, programas y encargos dispuestos a tal fin.

Recapitulando: si tenemos en cuenta las continuas prohibiciones contra la literatura de cordel promulgadas en el siglo XVIII por las autoridades civiles y religiosas, la animadversión mostrada hacia ella por las elites ilustradas y el discurso de Meléndez Valdés (texto clave en este asunto), la idea de que el poder usara conscientemente los pliegos sueltos como plataforma de propaganda nacional se viene abajo. Los romances, historias y relaciones que hemos analizado en estas páginas no formaron parte de un plan general urdido por las elites políticas. Obviamente, sí existieron textos de larga circulación al servicio de la monarquía, pero en ningún caso un programa ideológico aplicado de modo sistemático. Lo que no quiere decir que no existieran por entonces ideas y proyectos en este sentido: el discurso de Meléndez así lo indica, como también otros textos menos conocidos. En términos similares a los de Meléndez Valdés, el anónimo autor de una Memoria sobre la educación del hombre del campo, lamentando la degradación social que atribuía a

51 MelÉndeZ Valdés, op. cit. (nota 47), p. 1097 (la cursiva es nuestra). 
la difundida lectura de jácaras y romances ("esta peste que inficciona la jubentud, estremece a la humanidad, y llena de amargura a muchas honradas familias"), hacía un llamamiento a componer un nuevo romancero sobre "la historia de la Nación", la "historia sagrada", "algunos rasgos de la amistad, del amor filial, del agradecimiento, de la fidelidad, de la verdad, del amor a la patria", concluyendo que "este es el medio más adequado para mejorar las costumbres de nuestro Reino, y formar en él un pueblo austero, virtuoso y laborioso". ${ }^{52}$ Se reconocía, por tanto, la extraordinaria capacidad de divulgación de los romances y las posibilidades que ofrecían como soporte de ideas al servicio de la "utilidad pública" y de la "construcción nacional".

\section{Epílogo: la apropiación de "lo popular" por "lo nacional"}

El proyecto de Meléndez Valdés sería retomado años después, en otro contexto político, por Salustiano de Olózaga en su Informe sobre las ordenanzas de la hermandad de los ciegos, leído en la Sociedad Económica Matritense en $1834 .{ }^{53} \mathrm{Su}$ esquema argumental era similar: frente a la denostada literatura de cordel, urgía su prohibición y la creación de un nuevo romancero que restableciera "la austeridad y pureza de nuestras antiguas costumbres" (pp.181-182). Según Olózaga, las coplas y romances vendidas por los ciegos eran a todas luces dañinas a la nación:

Olvidadas las hazañas de tantos héroes españoles que antes todos conocían y cantaban, ignorado del pueblo entre tantos otros bellísimos romances ese precioso romancero del Cid, que a la par de las costumbres de nuestros mayores y de rasgos de valor propios solo de españoles, enseña ideas tan grandiosas y liberales, abandonados de las musas y hasta de la razón, entonan solo los ciegos coplas indecentes, aún más que por su bárbaro estilo y demás defectos literarios, por los hechos y los hombres que ensalzan (p. 126).

"El buen gusto, la moral pública y los intereses de la política" clamaban por la extinción de estos pliegos de cordel, cuyo hueco debía ser llenado a través de una "reforma diestramente manejada" para la elaboración de nuevas composiciones que fortalecieran "el instinto de la nacionalidad":

Diríjase a este punto la atención del gobierno y la de todos los patriotas ilustrados, y si dejando al ejercicio de la música la conveniente libertad y restableciendo el decoro que necesita, naciese en nuestro suelo, exencialmente poético, un hombre que como Beranger en Francia recogiese todas las tradiciones y recuerdos gloriosos para la nación, sintiese e hiciese sentir las necesidades de la época, explotase los sentimientos y las ideas dominantes, y asociase a las de la libertad bien entendida los intereses y hasta las preocupaciones de todas las clases de la sociedad, se verá concentrarse y fortale-

\footnotetext{
52 Mayordomo, Alejandro y LÁzAro, Luis Miguel (eds.): Escritos pedagógicos de la Ilustración, Madrid, Ministerio de Educación y Ciencia, 1988, vol. I, p. 117.

53 De Olózaga, Salustiano: Estudios sobre elocuencia, política, jurisprudencia, historia y moral, Madrid, 1864, pp. 115-135.
} 
cerse entre nosotros el instinto de la nacionalidad, sin el cual los pueblos no pueden ser independientes ni defender con tesón sus instituciones políticas (pp. 137-138).

Apenas dos años más tarde, en febrero de 1836, una real orden decretó la creación de una comisión de poetas que debía llevar a cabo los proyectos defendidos por Meléndez Valdés y por Salustiano de Olózaga. Integrada por los mejores literatos del momento (el duque de Rivas, Espronceda, Larra, Bretón de los Herreros, Pacheco, entre otros) la comisión debía preparar "los himnos de paz, de unión y de ventura" que difundirían "los hechos gloriosos y los rasgos cívicos dignos de imitación y alabanza". ${ }^{54}$ Finalmente, la reforma propuesta no pasó de ser un proyecto teórico, sin que la comisión diera fruto alguno en este sentido. Como tampoco lo dio, años después, el vano intento de Olózaga de proponer a José Zorrilla la creación de un nuevo romancero. ${ }^{55}$ Mientras estas iniciativas no pasaban del mero voluntarismo político, los pliegos de cordel siguieron difundiendo hasta el siglo XX los denostados romances, relaciones, historias y demás menudencias.

Sin embargo, a pesar del fracaso de estos proyectos, el vínculo que sus defensores establecían entre literatura popular y construcción nacional no se extinguió con ellos. Al contrario, gozó de gran fortuna, gracias a un giro intelectual por el cual la literatura popular dejó de contemplarse como un eficaz soporte de propaganda para pasar a ser concebida en sí misma como la pura esencia de la nación. Este giro se inscribe en el conocido proceso protagonizado desde finales del siglo XVIII por el Romanticismo, por el cual "el pueblo" se convirtió en materia de interés principal, casi de veneración, para muchos intelectuales europeos, en un proceso que Peter Burke denominó de manera reveladora como "el descubrimiento del pueblo". ${ }^{56}$

En España, la penetración de las concepciones románticas vino de la mano de los hermanos Schlegel, cuyas ideas fueron difundidas tempranamente por Juan Nicolás Böhl von Faber, hispanista alemán afincado en Cádiz y fecundo divulgador del romanticismo en España. ${ }^{57}$ August Wilhelm y Friedrich Schlegel defendieron el derecho de cada nación a desarrollar la expresión de sus propios sentimientos a través

54 Álvarez Barrientos, op. cit. (nota 46), pp. 313-314.

55 Ibidem, p. 314.

56 BuRke, Peter: La cultura popular en la Europa moderna, Madrid, Alianza, 1996, p. 35. Sobre los usos nacionalistas de "lo popular", véase Karnoouh, Claude: «On the Use of Folklore or the Avatars of Folklorism», Communication \& Cognition, 17-2/3 (1984), pp. 315-335; Díaz G. VianA, Luis: Los guardianes de la tradición. Ensayos sobre la "invención” de la cultura popular, Oiartzun, Sendoa, 1999, p. 65; ÁlvAREZ BARRIENTOS, J.: «Mito y falsificación del folklore: sus usos perversos», en La voz y el mito. Simposio sobre patrimonio inmaterial, Fundación Joaquín Díaz (edición digital), 2009, pp. 30-52; BuBnovA, Tatiana: «En torno a la cultura popular y a la otredad del pueblo», en CÁTEDRA, Pedro M. (dir.): La literatura popular impresa en España y en la América colonial. Formas \& temas, géneros, funciones, difusión, historia y teoría, Salamanca, Seminario de Estudios Medievales y Renacentistas, 2006, pp. 627-640; Prats, Llorenç: El mite de la tradició popular: els orígens de l'interés per la cultura tradicional a la Catalunya del segle XIX, Barcelona, Edicions $62,1988$.

57 JuREtschKe, Hans: «La presencia del ideario romántico alemán en la estructura y evolución teórica del romanticismo español», en GIEs, David T. (ed.): El romanticismo, Madrid, Taurus, 1989, pp. 304-319; Gies se refiere a la influencia de los hermanos Schlegel en España en Agustín Durán. A Biography and Literary Appreciation, London, Tamesis Books Limited, 1975, pp. 60-68; sobre el romanticismo español, véase, además de las citadas obras, PeERs, Edgard Allison: Historia del movimiento romántico español, Madrid, Gredos, 1973; Lloréns, Vicente: El romanticismo español, Madrid, Castalia, 1989. 
de sus propias y auténticas manifestaciones literarias, libres de toda injerencia extraña (en una clara referencia al difundido gusto francés). La auténtica poesía de cada nación se hallaba en la pluma de sus grandes maestros (Shakespeare en Inglaterra, Calderón en España), así como en su literatura popular, que reflejaba el espíritu y las tradiciones del pueblo, identificado con las esencias nacionales. Es significativo que ambos fijaran su atención en España para aplicar sus teorías: según Friedrich, "ninguna literatura ha conservado tan plenamente un carácter nacional como la española". ${ }^{58}$ No obstante, el romancero castellano, identificado con el espíritu popular, ya había sido objeto de atención para los primeros románticos alemanes: el propio Herder hizo una traducción en verso de los romances del Cid (1803), a través de la obra francesa Bibliothèque Universelle des Romans; Jacob Grimm publicó una Silva de romances viejos (1815), sacada principalmente del Cancionero de Amberes de 1555; igualmente, la colección de romances de G. B. Depping (1817), dedicada "a todos los amantes de la literatura española y de la poesía de la Edad Media", conoció un enorme éxito y fue traducida por Alcalá Galiano en 1844; Friedrich Diez publicó entre 1818 y 1821 sus Altspanische Romanzen, y otro tanto hizo Beauregard Pandin en 1823. Ferdinand Wolf recopiló varios romanceros, entre los que destacó su Rosa de Romances (1846), y Víctor Aimé Huber también dedicó diversos trabajos al tema. ${ }^{59}$

Los antiguos romances eran, a ojos de los románticos alemanes, una de las más puras expresiones de la poesía popular, un depósito centenario de las esencias de la nación española. La labor coleccionista no tardó en propagarse también por España, paralelamente a la difusión del romanticismo: estudiosos como Manuel José Quintana, Bartolomé José Gallardo, Juan Eugenio Hartzenbusch o el propio Böhl recopilaron romances, aunque entre todos ellos destaca la labor desarrollada por Agustín Durán con su Romancero General. Los romances castellanos fueron identificados por estos y otros eruditos con el alma de la nación española, la genuina creación del pueblo poeta, que debía ser salvaguardada y defendida de toda injerencia extranjera. Lo afirmó Durán expresivamente: "la emancipación del pensamiento en literatura es la aurora de la independencia, y el síntoma más expresivo de nacionalidad". ${ }^{60}$

Obviamente, los romances a los que se referían los estudiosos románticos no eran los que coetáneamente vendían y cantaban ciegos y copleros por las calles. Ya Herder había establecido la distinción entre "pueblo" y "vulgo": al noble Volk le separaba un abismo del populacho de su vecindario, esa "turba de las calles" que "nunca canta o versifica, sólo chilla y mutila". ${ }^{61}$ En España, la auténtica poesía popular, es decir, nacional, fue identificada esencialmente con los romances medievales atribuidos al inculto pueblo, surgidos "entre las más genuinas y sencillas [flores] de los prados y montes de lo popular, nacidas espontáneamente, y crecidas sin cultura y arte, sí, pero hijas de la fuerza creadora del sol de verano", en palabras de los compiladores

58 GIES, op.cit. (nota 56, 1975), p. 64

59 PeERs, op. cit. (nota 57), vol. I, pp. 130-131.

60 DurÁn, Agustín: Romancero General, o colección de romances castellanos anteriores al siglo XVIII, Madrid, Rivadeneyra, 1851, t. I, p. VI (nota 60).

61 Díaz G Viana, op. cit. (cita 56), p. 65. 
Ferdinand Wolf y Conrad Hofmann. ${ }^{62}$ Estos mismos autores hacían coincidir este surgimiento del romance con el origen de la nación castellana:

El origen de los romances debió coincidir con aquella época, en que, después de haberse desarrollado ya bastante su nacionalidad, cultura y lengua, los castellanos se sentían con un impulso irresistible de manifestar poéticamente su ser íntimo, su carácter nacional, y con los medios de hacerlo; y antes que la poesía artística comenzara a diferenciarse de la popular, es decir: con la época que media desde el siglo X al XII (pp. IX-X).

Es más: según Wolf y Hofmann, el hecho de que en el siglo XVI los poetas cultos admiraran estos romances medievales y se dedicaran a perfeccionarlos y embellecerlos, se debió esencialmente a la definitiva eclosión del espíritu nacional en España:

Este fenómeno singular no dejará admirado a quien considere que al comenzar el siglo XVI estuvo ya formada la base de la gran monarquía española; que en la primera mitad de este siglo los pueblos de los diferentes reinos, los castellanos, aragoneses, catalanes, navarros, granadinos, seguían juntándose a una gran nación, la española; que a mediados del mismo siglo los capitanes españoles habían sojuzgado la mayor parte de Italia al cetro de su rey, que era al mismo tiempo emperador de Alemania, y los conquistadores descubierto un nuevo mundo, anexándolo, como provincia, con el nombre de Nueva España, a la vieja. ¿Es, pues, de extrañar que por estos sucesos, por estas hazañas, se despertase el espíritu nacional con la mayor viveza y fuerza en el pueblo español; que la gloria actual resucitara la pasada, la memoria de los héroes nacionales; que los bizarros hijos del Cid entonaran de nuevo los cantares que celebraban las gestas de el que "en buena hora nació", con tanta lozanía y tanto vigor, que hasta los poetas de corte y de escuela no pudieron más ignorarlos, y por ser oídos se vieron forzados a mezclar su voz con la de los que "hacían estos romances"? (pp. XI-XII).

Sin embargo, sostenían estos y otros autores, desde finales del siglo XVI, y en paralelo a la progresiva decadencia de la monarquía hispánica, los romances verdaderamente populares fueron relegados y sustituidos por composiciones vulgares o plebeyas: la comparación entre la antigua y la nueva poesía constituía "el contraste más notable entre el antiguo pueblo ignorante con el del nuevo vulgo humillado y envilecido; de la barbarie que camina a la cultura, con la civilización que desciende a la barbarie". ${ }^{63}$ La literatura de cordel publicada desde el siglo XVII, por tanto, no merecía ya el calificativo de "popular", consideración que numerosos estudios (y no solo los folkloristas) han perpetuado hasta nuestros días.

Este giro intelectual, deudor del proceso de construcción nacional impulsado definitivamente por la burguesía liberal del XIX, hizo uso así de la literatura popular al servicio de la nación. Las coplas, relaciones y romances que venían difundiendo su heterogéneo caudal de textos e imágenes (algunos de los cuales, como hemos visto aquí, pudieron contribuir a la gestación de un sentimiento de pertenencia nacional)

62 Wolf, Ferdinand y Hofmann, Conrad: Primavera y flor de romances, ó Colección de los mas viejos y mas populares romances castellanos, Berlín, A. Asher y Comp., 1856, t. I, pp. III y IV.

63 Durán, op. cit. (nota 59), t. I, p. XXXII. 
fueron definitivamente denigrados como pasto de "un público iliterato o de rastrera literatura", mientras que los antiguos romances, extinguidos desde finales del siglo XVI, se identificaron con la auténtica poesía popular, el alma de la nación española, "la creación genuina en que la fuerte personalidad anónima de España une más impresionante su voz al gran coro de la poesía universal". ${ }^{64}$ La estrecha alianza establecida desde entonces entre "lo popular" y "lo nacional" quedó así firmemente sellada.

64 MenÉndez Pidal, Ramón: Romancero hispánico (hispánico-portugués, americano y sefardí), Madrid, Espasa-Calpe, 1953, t. II, pp. 247. 